\title{
Bureaucracy is constraining democracy in South African schools
}

\author{
MARIUS SMIT \\ Lecturer, Faculty of Education, North- West Province University
}

\section{INTRODUCTION}

Following the first democratic election in 1994 and the establishment of a constitutional democracy, ${ }^{1}$ South African society has been undergoing a fundamental transformation. In education, democratisation has been formalised with the redistribution and extension of power to local school governing bodies with the removal of centralised control over certain aspects of educational decision-making. ${ }^{2}$ The directive principle in section $4(\mathrm{~m})$ of the National Education Policy Act ${ }^{3}$ contains the democratic requirement that the national Minister of Education must ensure broad public participation in the development of the education by including stakeholders in policymaking and governance in the education system. ${ }^{4}$

The South African Schools Act $^{5}$ (hereafter the 'Schools Act') gave formal effect to the establishment of democratic structures of school governance which provide the basis for co-operative governance between education authorities and the school community. ${ }^{6}$ In principle these provisions were intended to establish a democratic power sharing and co-operative partnership among the state, parents, and educators. ${ }^{7}$ In terms of section 20 of the Schools Act, ${ }^{8}$ the authority of school governing bodies inter alia include the functions to:

- recommend the appointment of staff,

- determine the language policy of a school,

- take measures to ensure learner discipline at schools, and

- the responsibility for control of the school's property and financial resources.

1 De Waal Currie J, Currie I The new Constitutional and Administrative 1 ed Juta (2001) 40.

2 Oosthuizen IJ, Rossouw JP Fundamentals of Education Law (2003) Potchestroom: Azarel Publishers 195.

3 National Education Act 27 of 1996 at $s$ m.

4 Ibid.

5 South African Schools Act 84 of 1996.

6 Squelch JM "The establishment of new democratic school governing bodies: co-operation or coercion" in De Groof J, Brag E, Mothana S, Malherber R, Power sharing in Education: Dilemmas and implication for schools Leuven; Acco (1998) 101.

7 Karlsson J "Partnerships in current education and practice" in Groof (fn 6 above) 37.

8 South African Schools Act (fn 5 above) s 20. 
The transformation of the South African Education system has brought a spectrum of dilemmas regarding schools and democracy to light. According to Hilliard \& Notshulwana, ${ }^{9}$ it became evident after the transformation of the education system that there is still a lack of 'enlightened understanding' of the essential tenets of democracy. They state that democracy can take decades to evolve and is complicated by the fact that, prior to 1994, South Africa had never experienced a democratic culture. ${ }^{10}$ The different views of democracy are evident from the disagreements with regard to equal access to schools, transformation policies, public funding, inadequate stakeholder participation, public accountability and limitations on fundamental rights within the school system.

The focal point of these disputes has tended to be at the meso-level of the education system, i.e. between Provincial Education Departments on the one hand, and schools, parents or educators on the other.

\section{DEMOCRACY V BUROCRACY IN SOUTH AFRICAN SCHOOLS}

\subsection{Background}

Since the decentralisation of school governance in South Africa in 1996, a number of bureaucratic actions and incorrect administrative decisions by education administrators have lead to legal disputes that indicate a disregard for, or misunderstanding of the democratic values and principles that are necessary to promote effectiveness and efficiency in education. As in other countries, the major political and legal conflicts in public education have centred on questions of educational governance, processes and educators, and on the goals and benefits of education. ${ }^{11}$

For instance, the failure by education authorities to support school governing bodies' recommendations to expel ill-disciplined learners demonstrates an officious reluctance to take decisive action in the interest of good school governance. ${ }^{12}$ The unilateral appointment of educators contrary to school governing bodies' recommendations and legislative amendments exposes the intentional programme of provincial education authorities to re-centralise control and power in key issues in education. ${ }^{13}$ Legal disputes over the imposition of language policies by education authorities in contravention of the rights of school governing bodies indicate a bureaucratic disregard

9 Hillard VG, Notshulwana M "Strategies for ensuring sustainable democracy in South Africa" (2001) Acta Academica 155.

10 Hillard 151 (fn 9 above).

11 Harman G "Democracy, bureaucracy and the politics of education" as in Chapman, JS and Dustan JF Democracy and bureaucracy- tensions in public schooling (1990) New York Press 73.

12 Visser PJ "Failure by head of Education Department to act timorously and to interpret the law correctly- Maritzburg College v Dlamini, Mafa and Kondza case no 2089/2004 (as yet unreported)" (2005) Journal for Contemporary Roman-Dutch Law 702.

13 Beckman J "Aligning school governance and the law: Hans Visser on education cases and policy. A memorial lecture read in memory of the late Prof P.J. Visser" on 27 July 2007 at the University of Pretoria 6. 
for minority languages rights. ${ }^{14}$ Before the advent of democracy in 1994, Lardeyret ${ }^{15}$ warned that the prospects for sustainable democracy in South Africa are grim, if an effectively strong opposition and other mechanisms are not enhanced in order to ensure that accountability of public functionaries is exacted and the essential principles of democracy are adhered to by all. Since attaining democracy, the African National Congress (ANC) has consistently received overwhelming support in national elections. ${ }^{16}$ As a result the ANC has established an unassailable position as ruling political party in South Africa. Commentators have suggested that in reality, South Africa is a de facto one party democracy.

In this context, the controversial actions and decisions of the bureaucracy ${ }^{17}$ raises the concern that democracy in education is being constrained, and as a result, that the efficiency and optimal effectiveness of the education system is being undermined.

\subsection{Democracy in Education}

Cunningham ${ }^{18}$ explains that although the word democracy commonly invokes different conceptions, the shared core principles of liberal democracy include the notions of governance by the people, either directly through participation and deliberation, or indirectly through accountable and responsive representatives fairly by majority vote. Furthermore, democracy entails state protection of fundamental political and civil rights in terms of the rule of law and that the power of democratic institutions and pluralist interests are controlled by checks and balances and the separation of government powers. ${ }^{19}$ The South African Constitution ${ }^{20}$ comprises an integrated model of liberal democracy that provides for indirect representative democracy, pluralist checks and balances, enshrinement of fundamental rights, as well as direct deliberative and participatory controls, procedures and institutions. ${ }^{21}$

14 Malherber EF "The constitutional framework for pursuing equal opportunities in education" (2004) Perspectives in Education 14-15.

15 Lardeyert G "The problem[me] with PR" (In: the global resurgence of democracy) (1993) Diamond \& Partner Baltimore: John Hopkins University Press 164.

16 ANC attained a majority of $68,8 \%$ in the 2005 general election. See http://www.statssa.gov.za/ $/ \mathrm{html} /$ RSAPrimary.pdf 24 (accessed on 25-10-2007).

17 In her book Bureaucracy and Democracy Etzioni-Halevy (1983) 85 defines bureaucracy as a hierarchical organization of officials appointed to carry out certain public objectives. She concludes that although bureaucracies have not become more powerful than politicians, bureaucrats in most modern states have become sufficiently powerful to pose a threat to democracy by means of the ability to allocate resources, influence outcomes by administrative decision-making and by controlling positions of power.

18 Cunningham F Theories of democracy- a critical introduction Oxford and New York: Routlege (2002) 47.

19 Aspin DN "The conception of democracy: A philosophy for democratic education" as in Chapman J, Froumin I and Aspin DN London New York Press (1995) 33-34.

20 Constitution of the Republic of South Africa Act, 1996.

21 De Waal J (fn 1 above) 86-91. 
Participatory democrats have argued that more participation leads to increased effectiveness ${ }^{22}$ and should be encouraged. Pateman, ${ }^{23}$ Held $^{24}$ and Gould ${ }^{25}$ in particular, have proposed ways to democratise workplaces, the family, media, neighbourhoods, universities, schools, and decision-making about human relations to the natural environment. There are numerous modes of participation in the public education sphere including voting, campaigning, group activity, contacting representatives and officials, protesting, attending meetings, petitioning, fund-raising, canvassing and boycotting. ${ }^{26}$

Theoretically defined, deliberative democracy refers to the notion that legitimate political decision-making emanates from the public deliberation of citizens. In other words, as a normative account of political decision-making, deliberative democracy evokes ideals of rational legislation, participatory politics and civic self-governance. ${ }^{27}$ Habermas ${ }^{28}$ contends that the centrepiece of deliberative politics consists of a network of discourse and bargaining (compromising) that facilitates the rational solution of pragmatic, moral and ethical questions. According to Blaug and Schwartzmantel, ${ }^{29}$ the mere participation in the deliberation process confers legitimacy on the decisions, no matter what the respective outcomes may be.

With the increasing decentralization of fiscal, political, and administrative responsibilities to local spheres of government, local institutions, and communities, the notions of participation and deliberation have emerged as a fundamental tenet in the promotion of the local governance of schools. ${ }^{30}$ The policy of decentralization of education according to the principle of democratisation has become a key aspect of educational restructuring in the international arena. ${ }^{31}$ The international trend towards decentralization of education ${ }^{32}$ was necessitated by the following compelling reasons:

22 Barber RB "Strong democracy: Participatory politics for a new age" University of California Press (1984) 150.

23 Pateman C "Participation and democratic theory" Cambridge: Cambridge University Press (1970).

24 Held D "Models of Democracy" Oxford: Policy Press (1987).

25 Gould CC "Rethinking democracy: Freedom and social co-operation in politics, economics and society" Cambridge: Cambridge Press (1987).

26 Parry G, Moyser G "More participation, more democracy?" as in Beetham D Defining and measuring democracy London: Sage (1994) 46.

27 Cunningham (fn 18 above) 63.

28 Habermas J "Three normative models of democracy" as in Benhabib, S Democracy and difference: Contesting the boundaries of the political Princeton (1996) Princeton NJ: Princeton University Press 320 .

29 Blaug R, Schwarzmantel J Democracy- a reader Edinburgh (eds) Edinburgh University Press (2000) 359.

30 Grant L S, Naidoo J "Whose theory of participation? School governance and practice in South Africa, Current issues in comparative Education” (2004) New York: Columbia University 1.

31 Sayed Y "Discourses of the policy of educational decentralisation in South African since 1994: an explanation of South African Schools Act” (1999) Compare 141. Aspin (fn 19 above) 30.

32 Beare H "Democracy and bureaucracy in the organization of school systems" in Chapman JD, Duncan JF "Democracy and bureaucracy - tensions in public schooling" (1990) New York: The Falmer Press 16. 
- Education shapes democracy, and in turn, democracy inevitably shapes education; ${ }^{33}$

- Democratisation of governance systems in schools improves efficiency and accountability; ${ }^{34}$

- Political liberation of previously disenfranchised communities in South Africa impelled the insistence for greater participation by parents and stakeholders in education; ${ }^{35}$

- Following the Second World War, many developed nations attained almost universal levels of adult literacy. As a consequence of this educated parent population, demand for greater participation in matters involving education arose ${ }^{36}$

- Educator professionalism and improved levels of sophistication, especially in developed economies, instilled the confidence in the educator workforce to be less tolerant of bureaucratic dominance by centralised state administrations; ${ }^{37}$

- Development of theoretical models of deliberative democracy has raised the standards for enhanced equity and emphasised the need for joint decision making; ${ }^{38}$

- Economic successes of democratic business systems served as influential incentives to apply corporate management ideas to improve education. ${ }^{39}$

As has been the case in South Africa, these demands converged into forces for the devolution of responsibilities and authority to school communities, which were previously the preserve of centralised state bureaucracies. ${ }^{40}$

Accordingly, this discussion will concentrate on the democratic concepts of public involvement by full participation, deliberation and shared decision-making in education, substantive protection of civil liberties in the education context and accountability of representatives, including the employed bureaucracy that give effect to the decisions of representatives.

\subsection{Bureaucracy defined}

The tensions between the demands and values of democracy and the necessity of bureaucracy have not dissipated with the rise of more complex patterns of governance that encompass multiple stakeholders, but have become even

33 Dieltiens VM "Democracy in education or education for democracy?: The limits of participation in South African school governance." M Ed Dissertation Faculty of Education, University of the Witwatersrand (2000) 5 .

34 Connors, McMorrow "Governing Australia's Public Schools: Community participation, Bureaucracy and devolution" in Chapman J, Froumin I, Aspin D Creating and managing the democratic school, London: Washington DC (1970) The Falmer Press 75.

35 Soudien C, Sayed Y "A new racial state? Exclusion and inclusion in education policy and practice in South Africa” (2004) Perspectives in Education 101-102.

36 Beare (fn 32 above) 15.

37 Beare (fn 32 above) 13 .

38 Habermas (fn 28 above) 320.

39 Beare (fn 32 above) 12.

40 Dieltiens (fn 33 above) 35. 
greater. ${ }^{41}$ Although democracy does not have links to bureaucracy in abstract theory, in practice however, every democracy in the world is dependent on an efficient bureaucracy to function legitimately. ${ }^{42}$ Bureaucracy is an essential feature of post-industrial societies in all organizations where complex and large administrative tasks need to be undertaken. ${ }^{43}$

The classic definition, originally put forward by Weber, ${ }^{44}$ describes bureaucracy as a system of administration with the following characteristics: hierarchy; impersonality (the work is conducted according to set rules, without arbitrariness or favouritism, and with little flexibility or discretion to deviate); continuity (the administrative offices constitute full-time salaried occupations, with security of tenure and prospects for regular advancement); and expertise (officials are selected on merit, are trained for their function, and control access to knowledge and information because written record is kept of transactions).

However, apart from the positive features that improve the efficient and effective functioning of an organisation, bureaucracy is also associated with negative features such as 'red tape', non-accountability, unresponsiveness, delay, inflexibility, ineptitude, centralised elitism and undemocratic tendencies. ${ }^{45}$ As this paper focuses on the controversial aspects in education, the term bureaucracy (also education administration) will be used to denote these negative features.

\section{BUREAUCRATIC SUPPRESSION OF PARTICIPATORY DEMOCRACY IN EDUCATION}

The paragraphs that follow, contain an analysis of examples from reported case law to determine whether participation, in the aforementioned sense, by stakeholders in education is being constrained by bureaucracy in South Africa.

\subsection{Expulsion of ill-disciplined learners}

In the matter of Pearson High School $v$ Head of the Education Department, Eastern Cape Province, ${ }^{46}$ the Head of the Department of Education refused to confirm the expulsion of a learner and ordered that the learner, who had committed a serious misconduct, should return to the school. The salient facts of the case were that about two months earlier the learner, aged 15 (whose name was kept confidential in the Court proceedings by virtue of his minority) was a pupil at another school, Grey High School, Port Elizabeth. He was accused of stabbing four fellow learners with the needle of a medical syringe. Following this incident, the learner was removed from Grey High School and

\footnotetext{
41 Meier KJ, O’Toole LJ, "Bureaucracy in a democratic state - a governance perspective." (2006) John Hopkins 122.

42 Meire KJ (fn 41 above) 1.

43 Harman (fn 11 above) 62.

44 Weber M, "Economy and society:" as translated by Fischoff E (1968) 8.

45 Harman (fn 11 above) 63.

46 [1999] JOL 5517 (Ck).
} 
placed at Pearson High School. The principal of Pearson High School agreed to give the learner another chance on condition that he expressed special commitment to the ethos and rules of the school.

However, in less than a month after being admitted to the new school this learner was found guilty of the serious misconduct of purchasing dagga (marijuana) on the school grounds. After a fair disciplinary hearing the school governing body recommended that he be expelled from the school. Nevertheless, the Head of Department disallowed the expulsion and ordered that the learner return to the school. This forced the school to launch an urgent application to the High Court for the review of the education official's decision. The factors that the court considered were the necessity for good discipline in the interest of other learners at the school, the protection of educators, upholding standards of education, concerns of the parent body as well as the seriousness of the misconduct and prior infringements of the learner. The Court ordered that the decision of the Head of Department be set aside, that the learner be expelled from the Pearson High School and that the Education Department be ordered to pay the legal costs.

Although justice prevailed in this particular instance, this case is an example of inappropriate bureaucratic decision-making, which had detrimental consequences for school discipline and educational efficiency of the school. The court order remedies the administrative injustice of the bureaucratic decision, but does not address the shortcomings inside the bureaucracy.

\subsection{Illegal administrative decision-making}

Inflexible or illegal decision-making by education officials is illustrative of bureaucratic actions that disregard or suppress the rights of educators and school governing bodies. An example is the case of Simela $v$ MEC for Education, Eastern Cape ${ }^{47}$ where the Provincial Department of Education failed to obtain the prerequisite consent from educators to be transferred, when the entire professional staff of a school was "seconded" to other schools as a punitive measure. The first requirement for a valid transfer or appointment in terms of section 8 (1) (a) of the Employment of Educators Act $^{48}$ is that an affected educator must give prior approval and consent to the intended appointment, transfer or promotion. The educators were simply given copies of the report of a 'task team', which concluded that they were all guilty of various acts of misconduct. The educators sought a court order restraining the Department of Education from taking any steps to implement their transfers, and applied for reinstatement to the posts from which they had been transferred.

The court held that the provisions relating to the transfer (or appointment) of educators in the Employment of Educators $\mathrm{Act}^{49}$ require the consent of the affected educators. No such consent had been obtained. With regard to the

\footnotetext{
472001 (9) BLLR 1085 (LC).

48 Employment of Educators Act 76 of 1998.

49 Employment of Educators Act (fn 48 above).
} 
exercise of bureaucratic authority, Francis AJ expressed the court's opinion as follows:

"The Constitution affords everyone "the right to administrative action that is lawful, reasonable and procedurally fair". This means that every exercise of public power must, in order to be constitutional, be mandated by law, be performed in good faith by a decisionmaker who has not misconstrued his or her powers, be rational, and be conducted with due regard to the rules of natural justice." ${ }^{50}$

The court further held that fundamental to the notion of fair administrative action is that people have a right to be heard before their liberty, property, existing rights or legitimate expectations are prejudicially affected. The court found that the allegations contained in the task team's report pointed to serious disciplinary offences, which called for disciplinary action against individual educators in terms of Chapter 5 of the Employment of Educators Act. ${ }^{51}$ The Education Departments' reluctance to take disciplinary action and the decision to remove the all the educators from their posts under the guise of a purported secondment, pointed to an attempt to avoid the unpleasantness and effort associated with disciplinary action. The bureaucratic manner in which the Education Department summarily transferred the educators and the 'shotgun' approach of removing the entire staff from their posts on the basis of untested allegations was unconstitutional, inherently unfair, disproportionate, and contrary to the interests of education. As to relief, the Court declared the transfers void, reinstated the educators in their posts and ordered the Education Department to pay the legal costs of the lawsuit.

Similar cases have occurred fairly regularly. ${ }^{52}$ In an analogous ${ }^{53}$ matter the Free State High Court described the bureaucratic orchestration of a dismissal of a large number of educators from various public schools by the Head of Education as "shocking", "shameful" and "scandalous". In the unreported case of Suid-Afrikaanse Onderwysunie v Departementshoof Departement van Onderwys, Vrystaat, 2004 the Free State Education Department once again devised a scheme to dismiss 1200 temporary educators. The administratively unjust and unlawful decision of the Free State education authority was again set aside by the court.

These cases confirm a definite bureaucratic trend indicating that education authorities are disregarding the legal requirements for justly and fairly transferring or dismissing educators. Although the courts have by way of relief made punitive cost awards against blatantly unlawful bureaucratic action, ${ }^{54}$ this has not deterred the education authorities from repeating such unlawful action in another guise. ${ }^{55}$

50 Ibid (fn 47 above).

51 Employment of Educators Act (fn 48 above) chapter 5.

52 Nelson v Member of the Executive Council [2001] JOL 8152 (Ck); Observatory Girls Primary School v Head of Department of Education Guateng 2003 (4) SA 246.

53 Suid-Afrikaanse Onderwysunie v Departementhoof Departement van Onderwys, Vrystaat 2001 (3) SA $100 \mathrm{O}$.

54 Suid Afrikaanse Onderwysunie v Departmentshoof Departement van Onderwys Vrystaat 2001 (3) SA $100 \mathrm{O}$.

55 Suid Afrikaanse Onderwysunie v Departementshoof Departement van Onderwys, Vrystaat case no $1897 / 2004$ (as yet unreported). 


\subsection{Appointment of educators}

Another controversial area evidencing bureaucratic interference concerns the appointment of educators. The procedure to be followed when appointing an educator is described in the regulations of the Employment of Educators Act ${ }^{56}$ under the heading "Personnel Administration Measures". In terms of section 20(1)(i) of the Schools Act, ${ }^{57}$ and section 8 (2) of the Employment of Educators Act $^{58}$ no appointment or transfer of an educator to a public school may be made unless the recommendation of the governing body had been obtained.

As a result of bureaucratic interference with the rights of school governing bodies to recommend the appointment of educators, the legality of the bureaucratic decisions of the respective provincial Departments of Education have been challenged in a number of court cases (Carnavon High School and another $v$ MEC for Education, Northern Cape; Douglas Hoërskool $v$ The Premier of the Northern Cape Province; Kimberley Girls High School v. Head of the Department of Education, Northern Cape Province; Settlers Agricultural High School v. Head of Department of Education, Limpopo Province). All of these cases, except Kimberley Girls High were decided in favour of the school governing bodies by virtue of illegal bureaucratic decision-making by the education departments.

The case of Settlers Agricultural High School v. Head of Department of Education, Limpopo Province is illustrative of the manner in which the education officials bureaucratically disregarded the democratic authority of the school governing bodies. This matter involved the appointment of a principal to a vacant post. All the legal procedures, including the advertising of the post, the interviewing and the recommendation requirements had been duly complied with. The governing body recommended that Mr. V, a white Afrikaans speaking candidate, be appointed in first choice of preference. However, the Education Department appointed the second candidate on the shortlist, Mrs. M., because the departmental employment equity plan favoured a black female candidate as an affirmative action appointment. The Education Department contended that it could not be expected to simply "confirm and rubberstamp" a recommendation of a governing body, but that it was obliged to take requirements of employment equity into consideration.

The school governing body contended firstly, that section 6(3) of the Act did not entitle the Head of Department to substitute his bureaucratic choice of candidate for that of the governing body; secondly, that section $7(1)(1)$ required that the ability of the candidate be considered as a factor in conjunction with the need to redress past imbalances. The court upheld both contentions of the school governing body. The candidate recommended by the governing body had outscored the nearest competing applicant by a considerable margin during the evaluation process. The High Court held that the best interests of the learners were of paramount importance in accordance

\footnotetext{
56 Employment of Educators Act (fn 48 above).

57 Schools Act (fn 5 above).

58 Employment of Educators Act (fn 48 above).
} 
with section 28(2) of the Constitution ${ }^{59}$ and accordingly that the most able candidate had to be appointed.

The extent of the number of cases involving bureaucratic interference with the right of school governing bodies to recommend the appointment of educators, confirms the bureaucratic intention to advance employment transformation without due regard to democratic participation by the elected school governing bodies.

\subsection{Re-centralisation}

As a result of the judicial defeats in the cases regarding the appointment and transfer of educators, the national department of education had the relevant troubling sections of the Schools Act $^{60}$ and the Employment of Educators $\mathrm{Act}^{61}$ amended in parliament on three occasions. The Education Laws Amendment Act, No. 48 of 1999 made provision for a time-frame within which a governing body must make its recommendations when an educator is appointed; the Education Laws Amendment Act, No. 53 of 2000 made provision for the appointment of educators to new public schools by the provincial Head of Department (and not a school governing body); and the Education Laws Amendment Act, No. 24 of 2005 provides that the school governing body must recommend at least three candidates and the provincial Member of the Executive Council for Education (MEC) may appoint any of the recommended candidates. The MEC may accordingly disregard the school governing body's preferred candidate and may appoint any candidate on the list of three recommended candidates, even if it is a less suitably qualified or experienced candidate.

The incremental amendments amount to re-centralisation of the function to recommend the appointment of educators and reflect a gradual erosion of the authority previously devolved to school governing bodies. This recentralisation of power is aimed at enabling education departments to bring about the policy of transformation of the educational system and workplace in accordance with demographic criteria.

\section{BUREAUCRATIC CONSTRAINT OF DELIBERATIVE DEMOCRACY IN EDUCATION}

\subsection{Unresponsiveness, red tape and delay}

In the matter of Maritzburg College $v$ C.R. Dlamini NO, ${ }^{62}$ three learners of a public school were involved in an incident in which a window of a hired bus was smashed. Two learners were found to be smelling of alcohol and a bottle of brandy was found in the third's kitbag. After a proper and fair hearing, the school governing body decided to recommend expulsion of two of the learners to the Head of the Department of Education, KwaZulu-Natal

\footnotetext{
59 Constitution (fn 20 above) $s$ 28(2).

60 Schools Act (fn 5 above).

61 Employment Educators Act (fn 48 above).
}

62 [2005] JOL $15075 \mathrm{~N}$. 
province. In the interim the learners were suspended in terms of section 9 (1) (b) of the Schools Act pending the outcome of the final decision by the Head of Department.

Despite numerous letters, telephone calls from the Governing Body and a meeting with the Head of Department, he failed to come to a decision on the expulsion of the learners for 21 months. Eventually, out of sheer desperation the SGB approached the High Court for a declaratory order. The Head of Department contended that section 9 (1)(a) of the Schools Act did not allow for learners to be suspended for more than one week and that the interim suspension pending a decision on expulsion was unlawful. Combrinck J found that the Head was incorrect in relying on the provisions of section 9(1) (a) of the Schools Act and the school correctly applied the provisions of the Act and regulations. The Court criticised the unresponsive bureaucratic attitude of the public official by stating (at page 18):

"I find it disturbing (to put it mildly) that a public official had to be galvanized into action to do his duty only when served with a court application. Even more disturbing is his attitude as spelt out in paragraph 11 of his answering affidavit, quoted earlier in this judgment, that there is '... no obligation on me to expeditiously make a decision on expulsion as a number of issues had to be considered by me'."

The Court declared the decision of the governing body to be lawful and gave a punitive costs award in favour of the school.

In Despatch High School $v$ Head of Department of Education, Eastern Cape, ${ }^{63}$ the Eastern Cape high court voiced its displeasure at the way in which the education department in that province had dealt with a complaint against a principal who had stolen a school cell-phone and had lied about it. The court specifically stated that the manner in which the respondent dealt with the concerns of the SGB regarding the continued presence of the principal at the school was far from satisfactory. The court faulted the respondent for displaying indifference to the 'understandable concerns' of the SGB. Had the Head of Department complied with the democratic obligation to be responsive to public involvement through deliberation, the need for the school to resort to litigation might well have been averted.

\subsection{Lack of transparency}

In the labour dispute of Jonkers $v$ Western Cape Education Department, ${ }^{64}$ the grievant was informed telephonically that he was appointed as principal of a school in February 1997. After the selection process had been found to be flawed, it was repeated. After eight months had elapsed, the grievant was then informed that the post had been disputed and a moratorium had been placed on the filling of the post. The objection to the process was subsequently upheld by an arbitrator, who ruled that the selection process should commence de novo. However, the arbitrator criticised the department of education for lack of adequate communication and transparency and stated: 
'Much of emotional distress and embarrassment caused to the grievant could have been minimized if all communications regarding selection and nomination are only made in writing and decisions should be promptly communicated to all interested parties.'

Similar instances of inadequate communication and lack of transparent decision-making occur regularly with regard to the appointment of educators. ${ }^{65}$ However, not all such cases are litigated and the reported matters are only the tip of the iceberg.

\subsection{Non-accountability}

In a sequel to the High Court decision of Head of Department of Education, Limpopo Province $v$ Settlers Agricultural High School, ${ }^{66}$ that was discussed in paragraph 5.3 above, the Head of Department applied to the Constitutional Court to have the matter reconsidered. However, the Constitutional Court refused to condone the late application in the interests of justice and furthermore commented on the failure of the public official to comply with three High Court cost awards against him. The Constitutional Court stated that:

"If the applicant has indeed ignored the order for costs made against him in the earlier proceedings that would indicate an unacceptable lack of respect for court orders. ... If governments do not obey the court, they cannot expect citizens to do so. Nothing could be more demeaning of the dignity and effectiveness of courts than to have government structures ignore their orders. ${ }^{67}$

Therefore, the matters referred to in this section confirm a marked trend that education officials in provincial departments of education are disregarding deliberative democratic controls such as responsiveness, discussion, reasonable justification of decisions, accountability and transparency in order to enforce the political objective of transforming the education system.

\section{BUREAUCRATIC INFRINGMENT OF LANGUAGE RIGHTS}

State protection in terms of the rule of law of political and civil liberties, which includes enshrined fundamental rights, constitutes a substantive and formal feature of liberal democracy. ${ }^{68}$ Section 7 of the South African Constitution, enshrines the protection of eleven official languages as fundamental rights of individuals and communities.

\subsection{Disregard of language rights of non-English learners}

The de jure National Education Language Policy (hereafter 'Language Policy') supports multilingualism by additive bilingual education based on the numerical formula model. This looks impressive on paper and sound reasonable, but according to Heugh, ${ }^{69}$ the de facto language policy differs vastly from these laudable ideals. In practice, the Language Policy pays mere lip service

\footnotetext{
65 Keti \& another $v$ Head of Campus, Umtata General Hospital and others [2006] JOL 17168 (Tk)

662003 (11) BCLR 1212 (CC) para 14.

67 Head of Department of Education (fn 66 above) para 14.

68 Cunningham at page 47 (fn 18 above).

69 Heugh K "Languages, development and reconstructing education in South Africa" (1999) Interna-
} tional Journal of Educational Development 301-313. 
to the promotion of multilingualism. ${ }^{70}$ English as the dominant language is promoted to the detriment of African languages and Afrikaans. ${ }^{71}$ When one considers what the Language Policy fails to say, the reason for the de facto practice is clear. The Language Policy omits to provide that mother tongue education should be the norm; it fails to provide that the State is obliged to make schools available in the mother tongues of learners where reasonably practicable in accordance with the numeric formula model; it fails to provide that endangered minority languages should be specially protected; it does not determine how much resource allocation and time would be equitable for the sustained short, medium and long term development of each language and it does not determine norms or standards to ensure that the language policy most supportive of general conceptual growth amongst learners is followed. As a result of these critical omissions the Language Policy becomes meaningless for minority languages such as the official African languages and Afrikaans.

In a plenary speech in national parliament on 14 September 2006, the Minister of Education, Ms. Naledi Pandor, ${ }^{72}$ said that the government was resolved to promote unity in diversity at the school level in terms of both learners and employees. This statement confirms the government's emphasis on redress in order to transform the education system workplace of educators. Teacher's unions, predominantly representing African educators (SADTU), ${ }^{73}$ vociferously demand that English remains the common language of instruction at all schools in order that educators may have employment opportunities at any school. In order to appease the politically influential labour force, government policy and bureaucratic action promotes English as the language of instruction at schools, because integration into a monolingual education system will readily enable redress and transformation of the education system. If mother tongue instruction were to be advanced in schools, it would inevitably result in the formation of specific language schools. This implies that learners would then be encouraged to attend schools that offer instruction in their mother tongue. Likewise, educators proficient in the languages of instruction would have to teach at such schools. The overriding political resolve, on the other hand, is to transform the education system to an integrated and assimilated unity and to avoid linguistic differentiation.

However, as a result of the political decision not to promote de facto mother tongue education, the effectiveness of education in South Africa has deteriorated to such an extent that approximately $80 \%$ of all the schools were

70 Malherbe (fn 14 above) 14-15.

71 Foley E "Language policy for higher education in South Africa" (2004) South African Journal Higher Education 62.

72 Pandor N "Address by the Minister of Education at the language colloquium”, Cape Town, 31 July 2006 www.polity.gove.org/speeches as downloaded on 11 August 2006.

73 See South African Democratic Teachers Union "Memorandum of grievances: Demands for transformation of the education system". As handed to the Director or the Department of Education, Offices of the Southern Region of North-West Department of Education at Potchefstroom 21 September 2006. 
classified as dysfunctional in $2006 .{ }^{74}$ In 2005 , the results were so poor that only 150000 grade 12 learners (representing 12,5\% of the initial 1,2 million grade 1 learners) achieved a matric pass that is of an acceptable standard. ${ }^{75}$

\subsection{School governing body to determine language policy}

The issue of language policies at public schools has come to the fore in a number of court cases. In the matter of Laerskool Middelburg $v$ Departementshoof, Mpumalanga Departement van Onderwys, ${ }^{76}$ it was held that a decision by the provincial Education Department to enforce the inclusion of an English medium course on an Afrikaans medium school was an irregular and unjust administrative action. The court criticised the inordinately politicised action of the Education Department. It was irregular because the National Language Policy guidelines of filling available schools before requiring single medium schools to become double medium were not followed and the school governing body's right to determine the schools language policy was ignored.

In the matter of Governing Body of Mikro Primary School. $v$ Western Cape Minister of Education ${ }^{77}$. A similar set of facts was adjudicated by the Cape Provincial Division of the High Court. In this instance the provincial Education Department had once again enforced, at pains of disciplinary action, the inclusion of an English medium course upon an Afrikaans medium school, thus effectively changing the school language policy without regard to the democratic rights of the governing body. The action of the Education Department was found by the Thring J to "fly in the face of the law" because the Minister's language policy guidelines of filling available schools before requiring single medium schools to become double medium, were not followed. Thing J put it as follows:

"... it is the simple principle that the state must obey the law. That is a principle which is so fundamental and so important in any civilised country that it must be only extremely rarely, if ever, that the rule of law can be "held hostage".... to the best interests of children. Indeed, it is difficult to imagine how it could ever be in the best interests of children, in the long term, to grow up in a country where the State and its organs and functionaries have been elevated to a position where they can regard themselves as being above the law, because the rule of law has been abrogated as far as they are concerned. It could be cogently argued, I think, that a Court which, by its orders, exposed children to the risk of growing up in such a place would be doing them a greater disservice than a Court which merely ordered that they be removed from one school and placed in another, equally acceptable to their parents, and only a short distance away." ${ }^{78}$

The Western Cape Minister of Education took the matter on appeal. However, the Supreme Court of Appeal (SCA) unanimously confirmed the decision of the court a quo and dismissed the appeal with costs. The pattern of offi-

74 Taylor G "Focus on: Challenges cross in the education spectrum" (2006) 1-9.

75 Gallie C "If you want to solve your discipline problem[mes] in schools, dare to 'fix-up' adults first" International Conference on Perspective on learner conduct" as held at North West University, Portchestroom on 4 April (2007) 5.

762003 (4) SA 160 (T) 160.

772005 (3) SA 504 at 525 para A - C.

78 Governing Body, Mikro Primary School (fn 77 above) citing argument put by the council for the Second Respondent. 
cious interference with school governing bodies' rights to determine language policy has been repeated in the cases of Laerskool Seodin $v$ Department of Education, Northern Cape Province, 2005 and Ermelo Hoërskool v Departementshoof, Mpumalanga Departement van Onderwys, 2007.

The obvious answer to this predicament is not to pit transformation of the education system against democratic principles or fundamental individual or minority rights, but to improve the quality of education on the whole by improving the competence of educators and efficiency of the system, because this would be in the best interest of all children in the long run. Sachs J warned against this in In re: The School Education Bill of 1995(1996) by stating:

"The objective should not be to set the principle of equality against that of cultural diversity, but rather to harmonise the two in the interests of both. Democracy in a pluralist society should accordingly not mean the end of cultural diversity, but rather its guarantee, accomplished on the secure bases of justice and equity."

\section{CONCLUSION AND RECOMMENDATIONS}

This discussion has highlighted certain controversial bureaucratic practices that constrain the participatory, deliberative and liberal democratic principles in education. The underlying reasons for this phenomenon should be understood in the light of the political and social transformation that South Africa is undergoing. The stated political aim of the government is to ensure transformation of the workplace and other spheres of society in order to reflect the varied demography of the South African populace..$^{79}$ Also, the provincial education departments have embarked on administrative measures to promote equal access to English language education at all public schools in an attempt to redress past imbalances in education. However, advancing only English does not treat any of the eleven official indigenous languages equally and in effect gives English first language learners a distinct and unequal advantage above all other learners. Equal opportunity does not entail the equal encumbrance of all indigenous language learners, but should mean the opportunity to gain equal benefits by being educated in their own languages. Consequently, education officials are promoting certain policy decisions without due regard to the democratic principles of legitimacy (or 'the rule of law'), constitutionality, accountability, responsiveness and participation.

Although the need to transform the South African public education system remains a complex challenge, a reasonable balance must be maintained between the need to protect the individual from decisions unfairly arrived at by public authority and the contrary desirability of avoiding undue judicial interference in their administration. The courts play an essential role in controlling unjust and unlawful administrative actions that infringe the rights of schools such as the rights of governing bodies.

However, the role of the courts to address the trend of mal-administration and inept bureaucracy is limited to legal remedies and punitive cost awards

79 Pandor (fn 72 above) 1. 
on a case to case basis. Nevertheless, these remedies have not acted as deterrents to unlawful bureaucratic action. The Settlers and Suid-Afrikaanse Onderwysunie-cases strongly suggest that litigation and the judicial process is an unsuitable vehicle to systematically address the undemocratic trend of bureaucracy in education. This conclusion is based on the reality that individual administrators have 'bureaucratic immunity' against punitive cost awards or judicial relief against the state by virtue of the principle of vicarious liability by the state as employer. In none of the quoted cases were any punitive cost awards made against the officials personally, but always in their representative capacities as employees of the state.

Within the context of a de facto one-party democracy, such as South Africa, it is improbable that individual bureaucrats will be held accountable by political control for making unlawful decisions that align with the political objective of social transformation. The traditional methods of bureaucratic control, ${ }^{80}$ such as political control, or management control by strict discretionary guidelines, supervision and disciplinary action has not transpired and will in all probability not materialise in South Africa by virtue of the political objectives.

Consequently, in the absence of political will to control systemic undemocratic bureaucracy and the unlikelihood of change in government through elections, it is clear that judicial control and control by the independent constitutional institutions such as the Human Rights Commission and the Commission for the Promotion and Protection of the Rights of Cultural Communities, ${ }^{81}$ should be optimally utilised by aggrieved parties. Accordingly, it is recommended that effective legal remedies such as punitive cost awards against bureaucrats in their personal capacities, be applied by the judiciary (in appropriate cases) in the interest of promoting democracy through education.

\section{BILBIOGRAPHY:}

Aspin DN "The Conception of Democracy: A Philosophy for Democratic Education.” In: Chapman J, Froumin I, and Aspin, D.N. (eds.) Creating and Managing the Democratic School. London: New York: The Falmer Press (1995).

Barber RB Strong Democracy: Participatory Politics for a New Age. Berkeley: University of California Press.

Beare H Democracy and Bureaucracy in the Organization of School Systems. In: Chapman JD and Dunstan JF (Eds.) "Democracy and Bureaucracy - tensions in Public Schooling." London: New York: The Falmer Press (1990).

Beckman J. "Aligning School Governance and The Law: Hans Visser on Educa-

80 Meier (fn 41 above) 21-93.

81 De Waal (fn 1 above) 91. 
tion Cases And Policy." A memorial lecture read in memory of the late Prof PJ (Hans) Visser on 27 July 2007 at the University of Pretoria (2007).

Blaug R and Schwarzmantel J (eds.) Democracy - a reader. Edinburgh: Edinburgh University Press (2000).

Connor L G McMorrow JF “Governing Australia's Public Schools: Community Participation, Bureaucracy and Development" as in Chapman J Frouman I Aspin D (eds) Creating and Managing the Democratic School. London: Washington DC.: The Falmer Press (1990).

Cunningham F. Theories of Democracy - a critical introduction Oxford and New York: Routlege (2002).

Currie I and De Waal J (eds.) The new Constitutional and Administrative Law Vol 1 Lansdowne:Juta (2001).

De Wet JJ Montieth JL de K Venter PA \& Steyn H.S. Navorsingsmetodes in die Opvoedkunde - 'n inleiding tot empiriese navorsing. Durban: Butterworths (1981).

Dieltiens VM "Democracy in education or education for democracy?: The limits of participation in South African school governance" MEd dissertation Faculty of Education, University of the Witwatersrand. Johannesburg (2000).

Despatch High School $v$ Head, Department of Education, Eastern Cape, and others, 2003 (1) SA 246 (CKH).

Etzioni-Halevy E Bureaucracy and democracy: A political dilemma London Boston: Routledge \& Kegan Paul (1983).

Ex parte Gauteng Provincial Legislature: In re dispute concerning the constitutionality of certain provisions of the Gauteng School Education Bill of 1995 1996 (4) SA 172 (CC).

Foley E. "Language policy for higher education in South Africa: implications and complications." South African Journal Higher Education 62 (2004)

Gallie C. If you want to solve your discipline problems in schools, dare to 'fixup' the adults first! Address delivered at the International Conference on Perspectives on Learner Conduct held at North-West University Potchefstroom on 4 April (2007).

Grant Lewis S Naidoo "Whose Theory of Participation? School Governance Policy and Practice in South Africa. Current Issues in comparative Education" New York: Columbia University (2004).

Gould C C "Rethinking democracy: Freedom and Social Co-operation in Politics, Economy and Society.” Cambridge: Cambridge University Press (1998).

Governing Body, Mikro Primary School, and another $v$ Minister of Education, Western Cape, and others, 2005 (3) SA 504 (C)

Governing Body of Point High School $v$ Head of Western Cape Education Department, 2007 (SA). Unreported case no. 14188/2006 (WC).

Grove Primary School and others v Minister of Education, Western Cape, 1997 (4) SA 982 (C). 
Grove Primary School and others $v$ Minister of Education, Western Cape, 1997(4) SA 982 (C).

Habermas J "Three normative models of democracy" in Benhabib S. (ed) Democracy and Difference: Contesting the Boundaries of the Political." Princeton NJ: Princeton University Press (1996).

Harman G "Democracy Bureaucracy and the Politics of Education." In: Chapman JD and Dunstan J F (eds.) Democracy and Bureaucracy - tensions in Public Schooling. London: New York: The Falmer Press (1996).

Held D Models of Democracy Oxford: Polity Press (1987).

Heugh K. "Languages, development and reconstructing education in South Africa." International Journal of Educational Development. 301-313 (1999).

Hilliard VG, Notshulwana M "Strategies for ensuring sustainable democracy in South Africa." Acta Academica (2001).

Jonkers v Western Cape Education Department [1999] 2 BALR 199 (IMSSA).

Karlsson, J "Partnerships in current education and practice”. In: De Groof J Bray E Mothatha S \& Malherbe R (eds.) Power sharing in education: Dilemmas and implications for schools. Leuven: Acco (1998).

"Keti and Another v Head of Campus, Umtata General Hospital and Others" [2006] JOL 17168 (Tk).

Lardeyret G. The problem with PR. (In: The global resurgence of democracy (Diamond \& Plattner) (eds) Baltimore: John Hopkins University Press (1993)

Malherbe EF. The constitutional framework for pursuing equal opportunities in education Perspectives in Education. 14-15 (2004).

Maritzburg College v Dlamini NO and others [2005] JOL 15075 (N).

Meier KJ, O’Toole LJ Bureaucracy in a Democratic State - A Governance Perspective. Baltimore: (2006) The Johns Hopkins University Press.

Nelson v Member of the Executive Council [2001] JOL 8152 (Ck); 2002 (4) BCLR $325 \mathrm{Ck}$.

Oosthuizen IJ, Rossouw JP (2003). Fundamentals of Education Law. Potchefstroom:Azarel Publishers.

Pandor N Address by the Minister of Education at the language colloquium Cape Town, Monday, 31 July 2006. http://www.polity.gov.org/speeches [Date of access: 11 August 2006] (2006).

Parry G, Moyser G. More Participation, More Democracy? In: Beetham D (ed.) Defining and Measuring Democracy London:Sage (1994)

Parry G, Moran M. Democracy and democratization. Routledge: London and New York (1994).

Pateman C "Participation and Democratic Theory." (1970) Cambridge: Cambridge University Press. 
Pearson High School $v$ Head of the Department Eastern Cape Province and others [1999] JOL 5517 (Ck).

SA see South Africa.

SADTU see South African Democratic Teachers Union.

Samuel G Epistemology and Method in Law. Aldershot: Ashgate Publishing Limited (2003).

Sayed Y Discourses of the policy of Educational Decentralization in South Africa since 1994: an examination of the South African Schools Act (1) (2). Compare (1999).

Simela v MEC for Education, Eastern Cape [2001] 9 BLLR 1085 (LC).

Squelch JM "The establishment of new democratic school governing bodies: co-operation or coercion" In De Groof J Bray E Mothata S \& Malherbe, R. Power Sharing in Education: Dilemmas and implications for Schools Leuven: Acco (1998).

National Education Policy Act No. 27 of 1996.

South African Schools Act 84 of 1996.

Constitution of the Republic of South Africa Act 1996.

Employment of Educators Act. No. 76 of 1998.

South African Democratic Teachers Union. 2006. Memorandum of grievances: Demands for transformation of Education System. Copy of manuscript handed to the Director of the Department of Education, Offices of the Southern Region of North-West Department of Education at Potchefstroom during protest action on 21 September 2006 in possession of the author.

Soudien C, Sayed Y. "A new racial state? Exclusion and inclusion in education policy and practice in South Africa” (2004) Perspectives in Education. 22(4) $101-115$.

Statistics South Africa "An overview of South Africa” (2005)

Suid-Afrikaanse Onderwysunie v Departementshoof Departement van Onderwys, Vrystaat 2001 (3) SA $100(\mathrm{O})$.

Suid-Afrikaanse Onderwysunie v Departementshoof Departement van Onderwys, Vrystaat, Unreported case no. 1897/2004, High Court of South Africa, Free State Provincial Division.

Taylor G Focus on: challenges across the education spectrum JET Bulletin (15) 1-9 (2006).

Van Deventer HT "The value and practice of real partnership between learners, educators and the State as a means of sharing power on the institutional level of education" in De Groof J Bray E Mothatha S \& Malherbe R (Eds) 1998 Power sharing in education: Dilemmas and implications for schools Leuven: Acco (1998).

Visser PJ. Failure by Head of Education Department to act timeously and to interpret the law correctly - Maritzburg College v Dlamini, Mafa and 
Kondza Case no 2089/2004 (N) (2005) "Journal for Contemporary RomanDutch Law" 68(1): 698 - 702 (2005).

Weber M (ed.) Economy and Society. Translated by E. Fischoff et al. New York:Bedminster (1968).

Uitvlucht Primary School and another $v$ Head, Education Department Eastern Cape Province and another 2000 (1) All SA 238 (B). 